九州大学学術情報リポジトリ

Kyushu University Institutional Repository

\title{
DSC Thermogram and X-Ray Diffractometry of Bioplastics Prepared from Wheat Starch and Wheat Gluten
}

Lim, Jae-Kag

Laboratory of Food Technology, Faculty of Agriculture, Kyushu University

Fujio, Yusaku

Laboratory of Food Technology, Faculty of Agriculture, Kyushu University

https://doi.org/10.5109/23929

出版情報：九州大学大学院農学研究院紀要. 33 (3/4)，pp. 195-201，1989-03. Kyushu University バージョン：

権利関係 : 


\title{
DSC Thermogram and X-Ray Diffractometry of Bioplastics Prepared from Wheat Starch and Wheat Gluten
}

\author{
J ae-K ag Lim and Y usaku Fujio \\ Laboratory of Food Technology, Faculty of Agriculture, \\ Kyushu University 46-09, Fukuoka 812, Japan. \\ (Received September 10, 1988)
}

\begin{abstract}
Wheat starch with $23 \%$ moisture content and wheat gluten powder with $8 \%$ moisture content were successfully converted into plastic materials (bioplastics) by a plasticization treatment. The treatment was carried out in an air-tight cylindrical cell equipped with a heating device for the purpose of controlling the treatment temperature, and with a plunger for the purpose of appling a desired stress pressure. Based on density and DSC thermogram analysis of the obtained bioplastics, it was discovered that the stress pressure applied during the plasticization treatment dictated the molecular arrangements of wheat starch and wheat gluten. The $\mathrm{x}$-ray diffractometry confirmed that both bioplastics prepared from wheat starch and wheat gluten had non-crystalline structures.
\end{abstract}

\section{INTRODUCTION}

It has been well known that powderous starch and protein can be converted into plastic materials (bioplastics) by plasticization treatment under proper temperature and moisture conditions. Starch is normally composed of highly branched amylopectin molecules which are partially crystallized, and almost linear amylose molecules which have non-crystalline nature. Since the common starch obtained from various types of cereals contains both amylose and amylopectin, it is generally believed that natural starch is a biopolymer with some crystalline components. It has been found by the x-ray diffraction analysis (Nara et al., 1978 ; Zobel, 1988b) that the crystallinity of a purified wheat starch is $36 \%$. It has also been reported that natural wheat gluten is a non-crystalline biopolymer (Hoseney et al., 1986).

Wheat starch and wheat gluten can be melted under proper temperature and moisture content. Bioplastic materials can be obtained by cooling this molten materials. Characteristics of the bioplastics obtained by this procedure can play important roles in the development of new food processing technologies. One of such examples is the extrusion processing of food materials (Davidson et al., 1984 ; Lawton et al., 1985). Physical properties of the bioplastics obtained from wheat starch and wheat gluten are important information in studying such processing technology. However, not many fundamental study on physical properties, particularly characteristics at the temperature above $120^{\circ} \mathrm{C}$, have been reported to date. The study by Kohda et al. (1971) dealt with the characteristics of cereal-plastics obtained from wheat flour and rice grain. More recently, Fujio et al. (1988) reported the characteristics of wheat gluten heat-treated under air-tightly compressed conditions.

The purpose of this study was to reveal the characteristics of the bioplastics obtained by heat-treatment of wheat starch and wheat gluten at the temperature above 
$120^{\circ} \mathrm{C}$.

\section{MATERIALS AND METHODS}

\section{W heat starch and wheat gluten}

Moisture contents of wheat starch and wheat gluten (reagent grade, manufactured by Ishizu Pharmaceuticals Co., Ltd.) were adjusted to $23 \mathrm{wt} \%$ and $8 \mathrm{wt} \%$ respectively prior to the experiments.

\section{H eat-treatment conditions}

Koka Flow Tester (Shimazu Seisakusho Co., Ltd. Model 61323) was used for the heat-treatment of wheat starch and wheat gluten under stress pressure. The outline of the Flow Tester, details of the plunger loaded on cylindrical heating cell, and experimental procedures used for this study have been described in the previous report by Fujio et al. (1988). The raw material is heated in the heating cell to a specified temperature under a certain stress pressure applied by the plunger. Using the similar procedures, Fujio et al. (1988) have confirmed that both wheat starch and wheat gluten could be converted into bioplastics under a suitable combination of temperature and stress pressure. Such conditions are : temperature range $: 120-200^{\circ} \mathrm{C}$ for wheat starch and $60-180^{\circ} \mathrm{C}$ for wheat gluten, stress pressure range : $\mathrm{O}-200 \mathrm{Kg} / \mathrm{cm}^{2}$ for both wheat starch and wheat gluten.

The raw materials were at first heated for 2 minutes at a designated temperature without stress pressure, and then they were heated for another 3 minutes at the same temperature under a designated stress pressure. In this process, the moisture contained in the original sample was maintained without vaporization loss since the heating cell was air-tight. Cylindrical bioplastics materials $(11.3 \mathrm{~mm}$ in diameter and about 10-15 $\mathrm{mm}$ in length) were produced by cooling the heat-treated samples.

\section{Density of bioplastics}

Cylindrical bioplastic samples were cut into a desired length so that its volume and weight could be accurately determined. Density $\left(\mathrm{g} / \mathrm{cm}^{3}\right)$ of each sample was determined by these measurements.

\section{D ifferential scanning calorimetry (DSC)}

Bioplastic samples were soaked in liquid nitrogen for a few minutes in order to lyophilize them. The freeze-dried samples were immediately ground by a grinder to obtain 42 mesh undersize fine particles. The thermal transitions of these samples were measured with the differential scanning calorimeter manufactured by Seiko Electric Co., Ltd. (Model DSC 100). Weight of the sample powder prepared from each bioplastics was precisely weighed in a silver anti-leak pan. The moisture content of the samples obtained from wheat starch was adjusted to $70 \%$ by adding required amount of distilled water (weight of sample : weight of distilled water $=1: 2.3$ ). The moisture content of gluten samples were not adjusted. After weighing the pan and the sample, the pan was covered with a silver lid using a specially designed pan-press. Seal of the lid was intact at $200^{\circ} \mathrm{C}$ temperature applied during the integrity test. The pans with samples were kept at $4^{\circ} \mathrm{C}$ for a overnight in order to achieve a uniform moisture 
distribution, A pan with same amount of water was used as a reference in the case of wheat starch, while an empty pan was used as a reference for gluten samples.

Calibration of DSC was carried out by measuring the melting enthalpy of indium. Measurement of the endothermic enthalpy was carried out under the heating rate at $5^{\circ} \mathrm{C}$ per minute. The enthalpy was directly determined by measuring the area of endothermic peak using a mini-computer system equipped in the DSC unit.

\section{$X$-ray diffraction analysis}

$\mathrm{X}$-ray diffraction patterns were obtained for the same fine particle samples used for DSC analysis. The x-ray diffraction patterns were obtained by transmission of a diffractometer equipped with a monochrometer which was capable of selecting Ko radiation of a copper target, and with a scintillation counter. X-ray diffraction patterns for the bioplastics samples prepared from wheat starch at $10^{\circ} \mathrm{C}$ (no heattreatment) and $160^{\circ} \mathrm{C}$ under $200 \mathrm{Kg} / \mathrm{cm}^{2}$ stress pressure, and at $160^{\circ} \mathrm{C}$ without stress pressure were determined. X-ray diffraction patterns for bioplastics prepared from wheat gluten at $10^{\circ} \mathrm{C}$ (no heat-treatment), $70^{\circ} \mathrm{C}, 120^{\circ} \mathrm{C}$, and $160^{\circ} \mathrm{C}$ under $200 \mathrm{Kg} / \mathrm{cm}^{2}$ stress pressure were also determined.

\section{RESULTS AND DISCUSSION}

\section{Density variation of bioplastics}

Fig. 1 shows the density variation of the bioplastics prepared from wheat starch (1A) and wheat gluten (1B) under various treating conditions. Fig. 1A indicates some fluctuations in density at the stress pressure above $10 \mathrm{Kg} / \mathrm{cm}^{2}$, which appear independent from the treatment conditions. Since the accuracy of the measurement was same all cases, it was speculated that the cause of the fluctuations was associated with the heterogeneous nature of the bioplastics prepared from wheat starch. As it is evident from Fig. 1A, densities of the bioplastics prepared without stress pressure are much lower compared to the densities of bioplastics prepared under the existence of stress

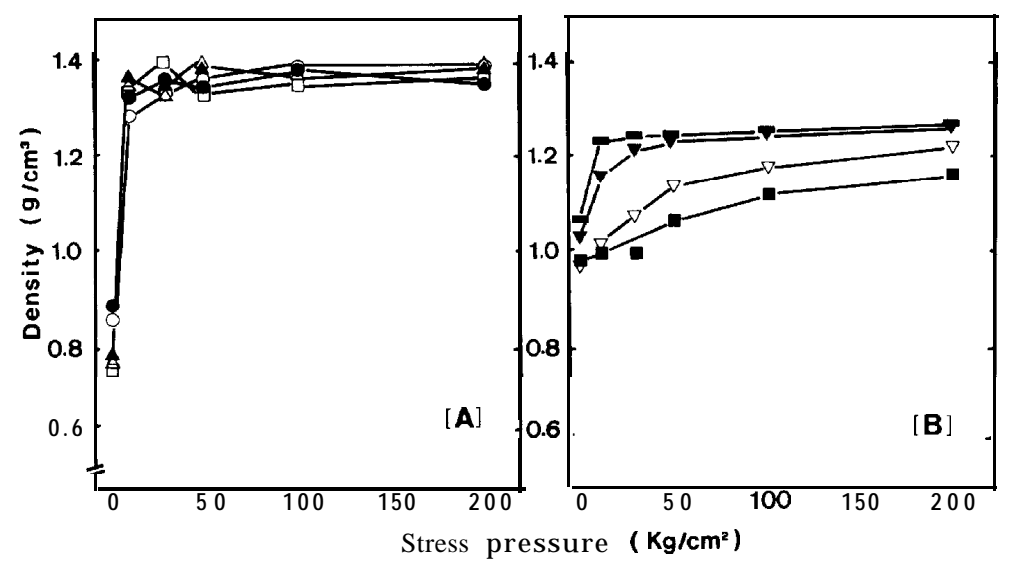

Fig. 1. Density variations of bioplastics from wheat $\operatorname{starch}(\mathrm{A})$ and wheat gluten(B). 
pressure. This fact suggests that wheat starch cannot be completely melted during the heat-treatment, allowing loosely arranged heterogeneous structure. As a result, the bioplastics prepared without stress pressure had a porous appearance.

In the case of the bioplastics prepared from wheat gluten, however, density variations with stress pressure levels were more smooth and systematic. This fact indicates that the bioplastics prepared from wheat gluten have more homogeneous structure, and their characteristics are dependent on treatment temperature and stress pressure level. Particularly at the treatment temperature below $120^{\circ} \mathrm{C}$, level of the stress pressure applied during the heat-treatment clearly dictated the density of the product bioplastics. It was observed that wheat gluten could be converted into bioplastics at a treatment temperature as low as $60-80^{\circ} \mathrm{C}$. However, the resultant bioplastics lacked transparency. These findings suggest that protein molecules in the bioplastics prepared from wheat gluten at the treatment temperature below $120^{\circ} \mathrm{C}$ are not completely melted. On the other hand, the level of stress pressure had almost no effect on the density of the bioplastics prepared at the temperature above $120^{\circ} \mathrm{C}$, except the case with no stress pressure which gave a significantly lower density. The average density of the bioplastics prepared from wheat gluten with $8 \%$ moisture content under the treatment temperature $120^{\circ} \mathrm{C}$ and the stress pressure $10 \mathrm{Kg} / \mathrm{cm}^{2}$ was $1.26 \mathrm{~g} / \mathrm{cm}^{3}$.

\section{DSC thermogram behavior of bioplastics}

Fig. 2 shows the DSC thermograms of the bioplastics prepared from wheat starch at various heat-treatment temperatures. Fig. $2 \mathrm{~A}$ was obtained without stress pressure, while (2B) was obtained under $200 \mathrm{Kg} / \mathrm{cm}^{2}$ stress pressure. In Fig. 2A, a thermogram of natural wheat starch is plotted with dotted line as a reference. The curve for the reference shows two endotherm peaks at $61^{\circ} \mathrm{C}$ and $101^{\circ} \mathrm{C}$. Endotherm enthalpies of these two peaks are $4.1 \mathrm{cal} / \mathrm{g}$ and $0.5 \mathrm{cal} / \mathrm{g}$ respectively. These endotherm enthalpies represent the changes in enthalpies when solid starch converted into gelatinized state. Similar thermogram data on wheat starch and rice starch have been reported by

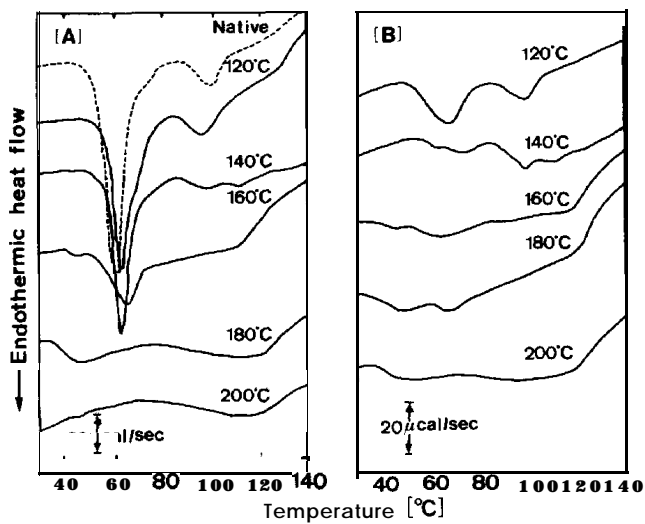

Fig. 2. Differential scanning calorimeter runs for bioplastics from wheat starch heat treated with stress pressure $\left(\mathrm{A}, 0 \mathrm{Kg} / \mathrm{cm}^{2} ; \mathrm{B}, 200 \mathrm{Kg} / \mathrm{cm}^{2}\right)$. Sample sizes on A (d. b., top to bottom) ; $2.5 \mathrm{mg}, 2.3 \mathrm{mg}, 2.3 \mathrm{mg}, 2.4 \mathrm{mg}, 2.1 \mathrm{mg}, 2.1 \mathrm{mg}$. Sample sizes on B (d. b., top to bottom); $2.0 \mathrm{mg}, 2.6 \mathrm{mg}, 2.5 \mathrm{mg}, 2.7 \mathrm{mg}, 3.1 \mathrm{mg}$. The water-to-starch ratio is $2.3: 1$ in all samples. 


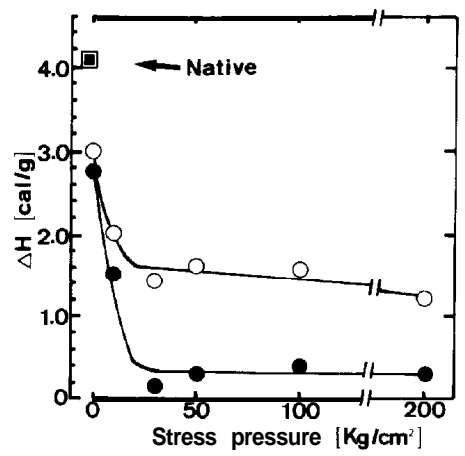

Fig. 3. Enthalpy change for the first endotherm of wheat starch as a function of stress pressure $0,120^{\circ} \mathrm{C} ; 140^{\circ} \mathrm{C}$

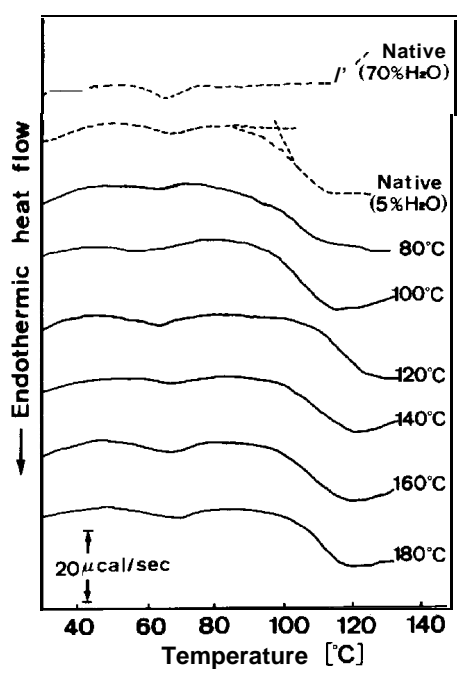

Fig. 4. Differential scanning calorimeter runs for bioplastics from wheat gluten heattreated with stress pressure of $200 \mathrm{Kg} / \mathrm{cm}^{2}$. Sample sizes (d. b., top to bottom) $; 2.5 \mathrm{mg}$, $3.5 \mathrm{mg}, 3.5 \mathrm{mg}, 3.9 \mathrm{mg}, 3.6 \mathrm{mg}, 4.0 \mathrm{mg}, 3.8 \mathrm{mg}, 3.6 \mathrm{mg}$. The water was not added to samples except native one $\left(70 \% \mathrm{H}_{2} \mathrm{O}\right)$.

Kugimiya et al. (1980), Lund (1984) and Yost et al. (1986). The thermogram for the wheat starch treated at the temperature below $160^{\circ} \mathrm{C}$ without stress pressure showed two peaks correspond with the two peaks for the natural starch shown in Fig. 2A. In contrast, DSC thermograms of wheat starch prepared by heat-treatment under $200 \mathrm{Kg} /$ $\mathrm{cm}^{2}$ stress pressure which are shown in Fig. 2B are significantly different from those shown in Fig. 2A.

Fig. 3 shows the integrated enthalpy values at $61^{\circ} \mathrm{C}$ as a function of stress pressure level. As it is shown in this figure, the integrated enthalpies for the samples prepared at $120^{\circ} \mathrm{C}$ and $140^{\circ} \mathrm{C}$ drastically decreased when the applied stress pressure reached about $30 \mathrm{Kg} / \mathrm{cm}^{2}$, at which point the endothermic values for both samples 


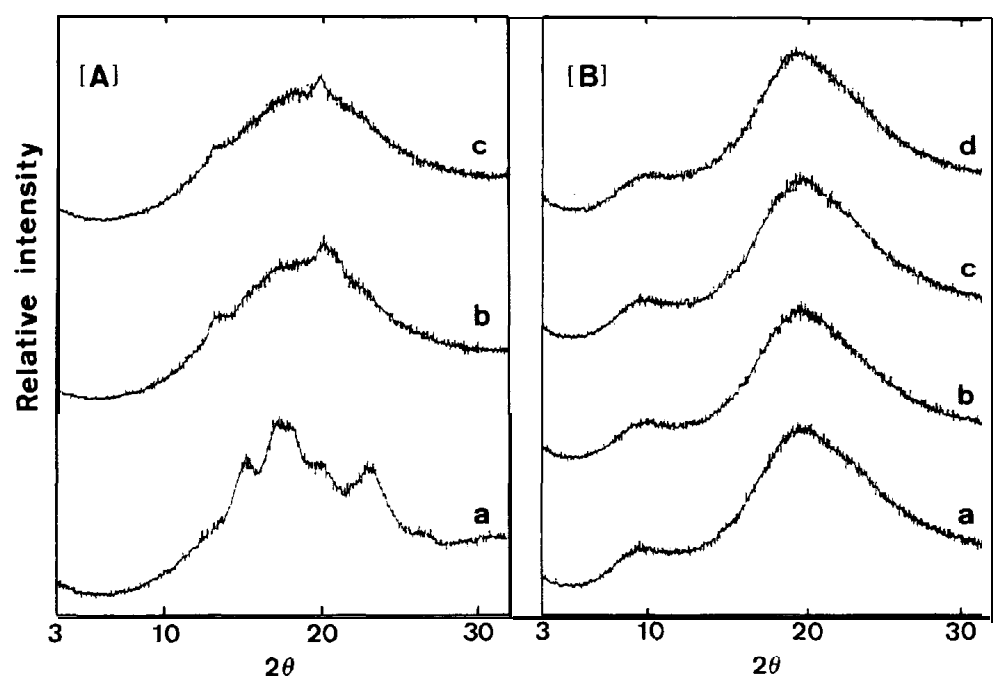

Fig. 5. X-ray diffraction patterns of bioplastics from wheat $\operatorname{starch}(\mathrm{A})$ and wheat gluten $(\mathrm{B})$.

A-a $: 10^{\circ} \mathrm{C}, 200 \mathrm{Kg} / \mathrm{cm}^{2} ; \mathrm{A}-\mathrm{b}: 160^{\circ} \mathrm{C}, 0 \mathrm{Kg} / \mathrm{cm}^{2}$;

A-c: $: 160^{\circ} \mathrm{C}, 200 \mathrm{Kg} / \mathrm{cm}^{2} ; \mathrm{B}-\mathrm{a}: 10^{\circ} \mathrm{C}, 200 \mathrm{Kg} / \mathrm{cm}^{2}$;

B-b : $70^{\circ} \mathrm{C}, 200 \mathrm{Kg} / \mathrm{cm}^{2} ; \mathrm{B}-\mathrm{c}: 120^{\circ} \mathrm{C}, 200 \mathrm{Kg} / \mathrm{cm}^{2}$;

B-d : $160^{\circ} \mathrm{C}, 200 \mathrm{Kg} / \mathrm{cm}^{2}$

approached constant levels. The constant endothermic value for sample prepared at $140^{\circ} \mathrm{C}$ heat-treatment was significantly smaller than that of $120^{\circ} \mathrm{C}$ treated sample. From the observation of Fig. 2 and Fig. 3, it can be concluded that higher the treatment temperature and the level of stress pressure (above $30 \mathrm{Kg} / \mathrm{cm}^{2}$ ), greater is the degree of randomness in starch molecule arrangement in the resultant bioplastics.

Fig. 4 shows DSC thermograms for the bioplastics prepared from wheat gluten under the treatment temperature at $80^{\circ} \mathrm{C}, 100^{\circ} \mathrm{C}, 120^{\circ} \mathrm{C}, 140^{\circ} \mathrm{C}, 160^{\circ} \mathrm{C}$ and $180^{\circ} \mathrm{C}$ and stress pressure at $200 \mathrm{Kg} / \mathrm{cm}^{2}$. A natural gluten with $70 \%$ moisture content showed only a slight endothermic peak at around $64^{\circ} \mathrm{C}$. This peak is believed to be caused by the gelatinization of starch existed in the gluten sample as a contaminant (Eliasson et al., 1980). However, natural gluten with 5\% moisture content showed a change in heat capacity on DSC thermogram at around $94^{\circ} \mathrm{C}$. This change in heat capacity suggests that the natural gluten is consisted of amorphous random polymers (Hoseney et al., 1986). Similar changes in heat capacity were also observed with the bioplastics prepared from wheat gluten treated at various temperatures under $200 \mathrm{Kg} / \mathrm{cm}^{2}$ stress pressure. The DSC patterns (not shown) for wheat gluten heat-treated without stress pressure were similar to the curves shown in Fig. 4. These results indicate that the bioplastics prepared from wheat gluten have amorphous random structures as well as thermoplastic nature.

\section{X-ray diffraction behavior}

Fig. 5 shows x-ray diffraction patterns of the bioplastics prepared from wheat starch and wheat gluten. Wheat starch treated at $10^{\circ} \mathrm{C}$ (corresponds to natural starch) 
showed a high degree of crystallinity in x-ray diffraction pattern. Similar patterns for cereal starch have been reported by Zobel (1988a). The crystalline structure of wheat starch was completely destroyed when it was heat-treated at $160^{\circ} \mathrm{C}$, giving $\mathrm{x}$-ray diffraction patterns similar to that of a typical amorphous material. Natural wheat gluten also showed almost no crystallinity on its x-ray diffraction pattern, which confirmed the common beliefs that a natural gluten was a non-crystalline biopolymer. The bioplastics prepared from wheat gluten at a higher temperature showed virtually no crystallinity at all. From these results, it can be concluded that the bioplastics prepared from wheat starch and wheat gluten under proper conditions can be a non-crystalline (amorphous) material.

\section{ACKNOWLEDGEMENTS}

We would like to thank Dr. Susumu Hizukuri, Professor of Kagoshima University, for his kind contribution in $\mathrm{x}$-ray diffraction and its analysis.

\section{REFERENCES}

Davidson, V. J., D. Paton, L. L. Diosady and G. Larocque 1984 Degradation of wheat starch in a single screw extruder ; Characteristics of extruded starch polymers. J. Food Sci., 49: 453-458

Eliasson, A. C. and P. 0. Hegg 1980 Thermal stability of wheat gluten. Cereal Chem., 5'7 : 436-437

Fujio, Y., J. K. Lim and I. Hayakawa 1988 Effect of temperature on solubility of wheat gluten heat treated under stress pressure. J. Fac.Agr., Kyushu Univ., 32 : 157-164

Hoseney, R. C., K. Zeleznak and C. S. Lai 1986 Wheat gluten ; A glassy polymer. Cereal Chem., 63 : 285-286

Kohda, Y. and T. Komiya 1971 Studies on plastic materials based on several cereals. J. Jap. Soc. Food Sci. and Technol., 18 : 366-369

Kugimiya, M., J. W. Donovan and R. Y. Wong 1980 Phase transitions of amylose-lipid complexes in starches ; A calorimetric study. Stiirke, $32: 265-270$

Lawton, J. W., A. B. Davis and K. C. Behnke 1985 High-temperature, short-time extrusion of wheat gluten and a bran-like fraction. Cereal Chem., $62:$ 267-271

Lund, D 1984 Influence of time, temperature, moisture, ingredients, and processing conditions on starch gelatinization. Crit. Rev. Food Sci. Nut., $20: 249-273$

Nara, S., A. Mori and T. Komiya 1978 Study on relative crystallinity of moist potato starch. Stiirke, $30: 111-114$

Yost, D. A. and R. C. Hoseney 1986 Annealing and glass transition of starch. Stärke, 38 : 289-292

Zobel, H. F. 1988a Starch crystal transformations and their industrial importance. Stärke, $40: 1-$ 7

Zobel, H. F. 1988b Molecules to granules ; A comprehensive starch review. Stärke, $40: 44-50$ 